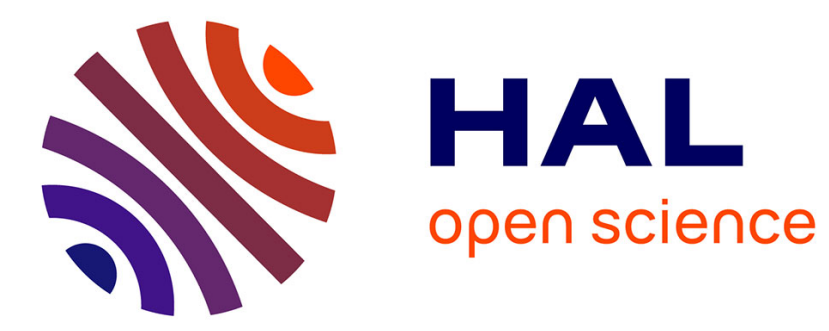

\title{
Benzodiazepine discontinuation among community-dwelling older people: a population-based cohort study
}

\author{
J. Simon Bell, Piia Lavikainen, Mikko Korhonen, Sirpa Hartikainen
}

\section{- To cite this version:}

J. Simon Bell, Piia Lavikainen, Mikko Korhonen, Sirpa Hartikainen. Benzodiazepine discontinuation among community-dwelling older people: a population-based cohort study. European Journal of Clinical Pharmacology, 2010, 67 (1), pp.105-106. 10.1007/s00228-010-0897-z . hal-00623787

\section{HAL Id: hal-00623787 \\ https://hal.science/hal-00623787}

Submitted on 15 Sep 2011

HAL is a multi-disciplinary open access archive for the deposit and dissemination of scientific research documents, whether they are published or not. The documents may come from teaching and research institutions in France or abroad, or from public or private research centers.
L'archive ouverte pluridisciplinaire HAL, est destinée au dépôt et à la diffusion de documents scientifiques de niveau recherche, publiés ou non, émanant des établissements d'enseignement et de recherche français ou étrangers, des laboratoires publics ou privés. 
Benzodiazepine discontinuation among community-dwelling older people: a population-based cohort study

J Simon Bell, PhD, ${ }^{1,2}$ Piia Lavikainen, MSc, ${ }^{1}$ Mikko Korhonen, MD,${ }^{3}$ Sirpa Hartikainen, MD, $\mathrm{PhD}^{1,2,3}$

1. Kuopio Research Centre of Geriatric Care, University of Eastern Finland, Kuopio, Finland

2. Clinical Pharmacology and Geriatric Pharmacotherapy Unit, School of Pharmacy, Faculty of Health Sciences, University of Eastern Finland, Kuopio, Finland

3. Leppävirta Health Centre, Leppävirta, Finland

Address for correspondence: Dr J Simon Bell, Kuopio Research Centre of Geriatric Care, PO Box 1627, University of Eastern Finland, Kuopio 70211, Finland, Fax: +35817162424

simon.bell@uef.fi

Word count: 551

Table: 1

Conflict of interest: The authors gratefully acknowledge funding provided by the Social Insurance Institution of Finland (SII). The authors declare that they have no conflicts of interest relevant to the content of the manuscript. Prof Hartikainen and Dr Korhonen are clinicians working in the municipality of Leppävirta.

Author contributions: Study concept and design (Bell, Korhonen, and Hartikainen), statistical analyses (Lavikainen), analysis and interpretation of data (all authors), drafting of manuscript (Bell), and critical revision of manuscript (all authors). 
To the Editor: Long-term use of benzodiazepines has been associated with advancing age, female gender, depression and use of $>2$ other prescription drugs [1-3]. Discontinuing benzodiazepines may improve body stability and daytime cognition without causing distressing withdrawal symptoms or emergent sleep difficulties [4-6]. The objective of this study was to investigate benzodiazepine discontinuation in the municipality of Leppävirta, located in Eastern Finland, from 2006-2008.

The study sample comprised all community-dwelling people aged $\geq 65$ years $(n=2415)$ in Leppävirta on August 31, 2006. Records of reimbursed drug purchases for 2006-2008 were extracted from the Finnish National Prescription Register maintained by the Social Insurance Institution of Finland (SII) [7]. Drugs were categorized using the Anatomical Therapeutic Chemical classification system. Benzodiazepines were defined as anxiolytics (N05B) and hypnotics and sedatives (N05C), which included zopiclone, zolpidem and zaleplon (N05CF). Patient diagnoses were extracted from the Special Reimbursement Register maintained by the SII. Diagnoses included endocrine disorders (diabetes, hypothyroidism), mental and neurological disorders (depression, epilepsy, psychosis, Alzheimer's disease, Parkinson's disease), cardiovascular disease (heart failure, hypertension, coronary artery disease, arrhythmias), respiratory disease (asthma, COPD) and musculoskeletal disorders (connective tissue injury, rheumatoid arthritis). Benzodiazepine use at baseline was defined as receipt of $\geq 1$ prescriptions for benzodiazepines in the six-months until August 31, 2006. Benzodiazepine use at follow-up was defined as receipt of $\geq 1$ prescriptions for benzodiazepines in the six-months until August 31, 2008. Logistic regression was used to investigate factors associated with benzodiazepine discontinuation between baseline and follow-up. To investigate the possible impact of patients being eligible for drug reimbursements in 2006 but not in 2008 sensitivity analyses were also performed excluding persons who received 3+ prescriptions in 2006 but zero prescriptions in 2008.

Among all people aged $\geq 65$ years $(n=2415), 346(14.3 \%)$ people received $\geq 1$ prescriptions benzodiazepines in the six-months until August 31, 2006. Of these 346 people, 311 were also alive in August 2008. Baseline diagnoses among these 311 people included 57 (18.3\%) endocrine disorders, 50 (16.1\%) mental or neurological disorders, 171 (55.0\%) cardiovascular disease, 11 (3.5\%) musculoskeletal disorders, 34 (10.9\%) respiratory disorders and $15(4.8 \%)$ cancer. At baseline, 193 (62.1\%) people received reimbursement for $\geq 5$ different prescription drugs in the sixmonths until August 31, 2006. Of the 311 people, 168 (54.0\%) also received $\geq 1$ prescriptions for benzodiazepines in the six-month period until August 31, 2008. Age 85+ years was significantly 
associated with benzodiazepine discontinuation in the multivariate analyses (Table 1). This remained significant in univariate (odds ratio [OR] 2.31, 95\% confidence interval (CI) 1.09-4.87) and multivariate (OR 2.20, 95\%CI 1.02-4.77) analyses when excluding persons who received 3+ prescriptions in 2006 but zero prescriptions in 2008.

Forty-six percent benzodiazepine users in 2006 were categorized as non-users at the two-year follow-up, with benzodiazepine discontinuation associated age $85+$ years. The high rate of discontinuation among the oldest old is encouraging because previous studies have reported that increasing age is associated with long-term benzodiazepine use [1,2]. Unlike in previous studies female sex, mental or neurological disorders and use of other prescription drugs were not associated with long-term use [1-3]. A strength of the study was that the Prescription Register included all reimbursed drug purchases for all residents in non-institutional settings. However, not all brands of small packs of benzodiazepines we reimbursed by the SII [8]. In conclusion, our results challenge the popular misconception that discontinuation is too difficult among the oldest old.

\section{REFERENCES}

1 Luijendijk HJ, Tiemeier H, Hofman A, et al. (2008) Determinants of chronic benzodiazepine use in the elderly: a longitudinal study. Br J Clin Pharmacol 65: 593-599

2 Cheng JS, Huang WF, Lin KM, Shih YT (2008) Characteristics associated with benzodiazepine usage in elderly outpatients in Taiwan. Int J Geriatr Psychiatry 23: 618-624

3 Stowell KR, Chang CC, Bilt J, et al. (2008) Sustained benzodiazepine use in a community sample of older adults. J Am Geriatr Soc 56: 2285-2291

4 Tsunoda K, Uchida H, Suzuki T, et al. (2010) Effects of discontinuing benzodiazepinederivative hypnotics on postural sway and cognitive functions in the elderly. Int J Geriatr Psychiatry Jan 6 [Epub ahead of print] DOI 10.1002/gps.2465

5 Curran HV, Collins R, Fletcher S, et al. (2003) Older adults and withdrawal from benzodiazepine hypnotics in general practice: effects on cognitive function, sleep, mood and quality of life. Psychol Med 33: 1223-1237

6 Iyer S, Naganathan V, McLachlan AJ, Le Couteur DG (2008) Medication withdrawal trials in people aged 65 years and older: a systematic review. Drugs Aging 25: 1021-1031

7 Furu K, Wettermark B, Andersen M, et al. (2010) The Nordic countries as a cohort for pharmacoepidemiological research. Basic Clin Pharmacol Toxicol 106: 86-94 
8 Rikala M, Hartikainen S, Sulkava R, Korhonen MJ (2010) Validity of the Finnish Prescription Register for measuring psychotropic drug exposures among elderly Finns: a population-based intervention study. Drugs Aging 27: 337-349 
Table 1. Factors associated with benzodiazepine discontinuation

\begin{tabular}{lll}
\hline & Unadjusted OR & Adjusted OR* \\
\hline Baseline age & & \\
$65-74$ & 1.00 & 1.00 \\
$75-84$ & $1.35(0.83-2.17)$ & $1.37(0.84-2.24)$ \\
$85+$ & $2.26(1.09-4.70)$ & $2.18(1.03-4.64)$ \\
Female sex & $1.46(0.91-2.33)$ & $1.38(0.85-2.24)$ \\
Baseline diagnoses & & \\
Endocrine disorder & $0.69(0.38-1.24)$ & $0.67(0.36-1.25)$ \\
Mental or neurological disorder & $0.75(0.40-1.39)$ & $0.76(0.41-1.43)$ \\
Cardiovascular disease & $0.97(0.62-1.52)$ & $0.89(0.52-1.51)$ \\
Musculoskeletal disorder & $1.43(0.43-4.78)$ & $1.46(0.43-4.97)$ \\
Respiratory disorder & $1.20(0.59-2.44)$ & $1.18(0.56-2.48)$ \\
Cancer & $0.77(0.27-2.23)$ & $0.77(0.26-2.30)$ \\
Use of $>5$ other prescription drugs & $1.13(0.72-1.79)$ & $1.20(0.70-2.06)$ \\
\hline
\end{tabular}

*Adjusted for age, sex, baseline diagnoses and use of $>5$ other prescription drugs

$\mathrm{OR}=$ Odds Ratio 